\title{
Expectations- Satisfactions- Needs of the Faculty of Fine Arts Students from the Design Programs and Solutions
}

\author{
Eylem Tataroglu ${ }^{1}$
}

\begin{abstract}
It is clear that changeability of this situation concerning being the "producer" and "conscious consumer" individuals, as almost in every respect, fundamentally could be provided with qualified training, the other suitable conditions and use the economic resources suitably. Since this research focuses on the training aspect, the suitable conditions and resources are defined mostly with the training environment, the existing technology, environment and family facts. These facts are evaluated with the youths being center of the training or the students, depending on them and directly related to them. Considering the importance of the technology in the field of design and fast transformation of the animated cinema, it is obvious that current situation is quantitatively insufficient. In addition, when the ideals of the youths studying at design are also taken into consideration, it is thought that not only quantitatively, but also qualitatively the current situation falls short of meeting the expectations. The vision of Başkent University in the art and design education being candidate to share the honor proven in the science was evaluated regarding the current educational environment, instructors, course contents and environmental factor and opportunities with the ideals of the students registered to the Graphic Design Program dependent on the Department of Visual Arts and Design; the results related to the ideals of students and the success of the program and suggestions regarding the solution of the current problems were evaluated. It is thought that the study will serve as a base search and needs analysis and it could be assessed as data in all the improvements which will be made for faculty.
\end{abstract}

Keywords: Design, Arts and Design Education, Graphic Design

\section{Introduction}

When the position of Turkey is considered in the technological construct of developing and evertransforming world, it is observed that Turkey keeps its "consumer" position according as in the other fields.

There are faculties under the name of Faculty of Fine Arts, Faculty of Communication or Faculty of Art and Design in the 82 university in our country and there are Graphic in 63 of them, Visual Communication Design in 32 of them and Animation or Animated Cinema only in 7 of them.

It is possible to see the transformation of art and design in the information and technology age in all of the published and mobile culture devices including consumption objects we use in our daily life primarily. As our daily life and habits, designed in a rather broad scale, interfuse our life as a "culture" object, if we are fortunate, they take strength from a design that is precious aesthetically, able to reproduce and thus sustainable. This design, at the same time as a work of transformable, progressive and creative thought, puts the people qualified in a certain type in the center and exists with its activity, with the property of being a product of human brain and human thought. In this case, an environment whose problems are solved and humans whose needs are met require the existence of a community which simply dreams that environment at the same time. Since people education and especially art education of people means a sensitivity development style and settling the consciousness of selecting what is "beautiful", it is extremely crucial.

The designers of all objects and materials, which have different functions and various aesthetic appearances in our daily life, have certainly a deep perception, insight, skill and sound knowledge device. This device, a result of education supporting innate creativity, is granted in a "fundamental" level in formal education institution before university education. One of the basic targets of art and design faculties in higher education institutions is to raise designers needed by a country. The present study was structured to determine the place of Başkent University students, who receive art and design

This article is published under the terms of the Creative Commons Attribution License 4.0

Author(s) retain the copyright of this article. Publication rights with Alkhaer Publications.

Published at: http://www.ijsciences.com/pub/issue/2016-06/

DOI: 10.18483/ijSci.1060; Online ISSN: 2305-3925; Print ISSN: 2410-4477 
education, in design education based on interest, necessity, expectation and future design, and the state of Turkish universities to answer needs was assessed based on the current programs.

When the investigation focused on the expectations and dreams of the students, it was understood that the majority wished to have a graduate education for certain following their current undergraduate education.

\section{Method}

This research was conducted by using a "school survey" based on general scanning model. General scanning models are scanning arrangements made on the entirety of the universe or on a group, sample or example in order to pass a general judgment about the universe, which is made of scores [4, p18] The data were solved by using SPSS 11.0 (Statistical
Package for the Social Science) and turned into graphs in percentiles.

\section{Results and Comment}

This research was conducted by reaching 40 students out of a total of 65 students who are attending Başkent University, Fine Arts, Design and Architecture Faculty in 2014-2015 academic year, and registered in Fine Arts and Design Department, Graphic Design Program.

The survey used in the research is made of a total of 5 sections. Section 1 is for determining demographic characteristics. Section 2 attempted to determine student ideals. Section 3 is about the current education setting where the physical conditions of the students were evaluated. Section 4 analyzes educational components of the students and class contents. Section 5 is the last section where we collected data about their plans for the future.

All data are valid.

The data are represented as follows:

Section 1: Demographic Characteristics

Table-1: Gender

\begin{tabular}{|l|l|}
\hline Women & $16(40 \%)$ \\
\hline Men & $24(60 \%)$ \\
\hline
\end{tabular}

$40 \%$ of the students were women, $60 \%$ were men.

Table-2 : Age

\begin{tabular}{|l|l|}
\hline $18-23$ & $28(70 \%)$ \\
\hline 23 and above & $12(30 \%)$ \\
\hline \multicolumn{2}{|l|}{$70 \%$ of the students were in the range of $18-23$ of age and $30 \%$ were over 23 years of age. }
\end{tabular}

Table-3: Level

\begin{tabular}{|l|l|}
\hline $1^{\text {st }}$ grade & $18(45 \%)$ \\
\hline $2^{\text {nd }}$ grade & $14(35 \%)$ \\
\hline $3^{\text {rd }}$ grade & $4(10 \%)$ \\
\hline $4^{\text {th }}$ grade & $4(10 \%)$ \\
\hline
\end{tabular}

$45 \%$ of the students were in $1^{\text {st }}$ grade, $35 \%$ is in the $2^{\text {nd }}$ grade, $4 \%$ were in the $3^{\text {rd }}$ grade and the remaining $4 \%$ were in the $4^{\text {th }}$ grade.

Table-4: Grade repeating

\begin{tabular}{|l|l|}
\hline Grade repeating students & $6(15 \%)$ \\
\hline Not repeating students & $34(85 \%)$ \\
\hline
\end{tabular}

$15 \%$ of the students repeated grade.

Graduation (high school) and dwelling unit

12 of the students were graduates of colleges located in Ankara. Only 2 of them were graduates of Fine Arts Anadolu High School in Ankara, and 3 of them completed high school in provinces other than Ankara. 37 students were graduates in Ankara.

Table-5: Students living with their families

\begin{tabular}{|l|l|}
\hline Students living with their families & $34(85 \%)$ \\
\hline Students not living with their families & $6(15 \%)$ \\
\hline
\end{tabular}

$85 \%$ of the students lived with their families.

Students not living with their families and the places they live

1 of the students lived in dormitory, 4 lived alone, and 1 lived with his relatives. 


\begin{tabular}{|l|l|l|l|l|l|l|l|l|l|l|l|l|l|}
\hline $\begin{array}{l}\text { Student } \\
\text { number }\end{array}$ & 13 & 5 & 6 & 2 & 1 & 2 & 1 & 2 & 1 & 2 & 1 & 3 & 1 \\
\hline $\begin{array}{l}\text { Monthly } \\
\text { income of } \\
\text { students }\end{array}$ & 1000 & 1500 & 2000 & 2500 & 300 & 400 & 4000 & 500 & 5000 & 600 & 6000 & 700 & 800 \\
\hline
\end{tabular}

29 of the students received stipend of 1000 and more.

Section 2: Student Ideals

Table-7: "Attending graphic design program was my ideal."

\begin{tabular}{|l|l|}
\hline Yes & $30(75 \%)$ \\
\hline No & $10(25 \%)$ \\
\hline
\end{tabular}

$75 \%$ of the students regarded the graphic design program as their university ideals.

No: One of the students indicated radio, TV and cinema as his ideal, the others indicated fields such as computer engineering, law, physical education, political sciences, business, tourism, automotive engineering, and economy as their ideals.

Table-8 : “Attending Başkent University, Faculty of Fine Arts, Design and Architecture was my ideal."

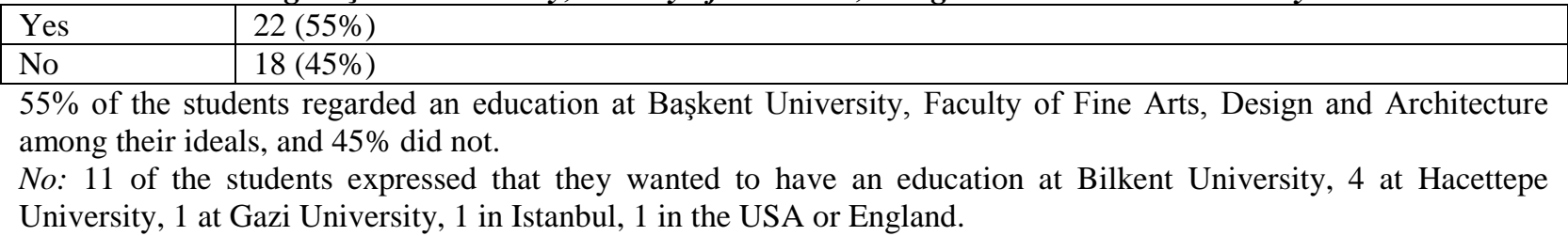

Table-9 : "My family adapted an "overbearing” and "insistent" attitude about my university and department selection."

\begin{tabular}{|l|l|}
\hline Yes & $1(2,5 \%)$ \\
\hline No & $39(97,5 \%)$ \\
\hline
\end{tabular}

Only 1 of the students $(2.5 \%)$ indicated that he faced family pressure and insistence in his university and department selection.

Table-10: "I attend this university and department because my scores allow me to have an education only in this department of our university."

\begin{tabular}{|l|l|}
\hline Yes & $14(35 \%)$ \\
\hline No & $26(65 \%)$ \\
\hline
\end{tabular}

$35 \%$ of the students expressed that they preferred this department because their scores were sufficient for this department.

Table-11: "The graphic design education I am receiving right now meets my graphic design expectations that I aimed/dreamed in the following level":

\begin{tabular}{|l|l|}
\hline Not met absolutely & $5(12,5 \%)$ \\
\hline Met partially & $24(60 \%)$ \\
\hline Met completely & $11(27,5 \%)$ \\
\hline
\end{tabular}

$12.5 \%$ of the students expressed that the education they are having did not meet their expectations; and the remaining indicated that it met their expectations partially or completely.

Section 3: Existing Education Setting (Physical Conditions)

Table-12: "I think that the existing classrooms are suitable to teaching theoretical lessons."

\begin{tabular}{|c|c|}
\hline Yes & $30(75 \%)$ \\
\hline No & $10(25 \%)$ \\
\hline \multicolumn{2}{|c|}{$\begin{array}{l}\text { 75\% of the students found the existing setting sufficient in terms of the physical setting where classes will be } \\
\text { thought. } \\
\text { Table-13: "I think that the existing studios (workshops) are suitable for teaching practical lessons." }\end{array}$} \\
\hline Yes & $29(72,5 \%)$ \\
\hline No & $11(27,5 \%)$ \\
\hline
\end{tabular}

It was determined that $72.5 \%$ of the students thought that the existing studios are suitable for teaching practical lessons.

Table-14: "I think that the current technological infrastructure and equipment is sufficient for all of my studies 
that need to be carried out in digital setting."

\begin{tabular}{|l|l|}
\hline Yes & $20(50 \%)$ \\
\hline No & $20(50 \%)$ \\
\hline
\end{tabular}

The students were divided into two in terms of the sufficiency of the existing technological infrastructure and equipment.

What I think about making the current classrooms more suitable for teaching theoretical classes are:

- Carry out maintenance and controls of equipment such as computer and projections in the classrooms regularly.

- The walls of our classrooms and the faculty can be shaped as more suitable for us. There must be photographs, paintings, and art works to inform us always about art as we go through the corridor to the buttery. There must be visual information not only during class but also even when we enter the classroom and look at the walls to add something to themselves any moment. Moreover, these works should be changed in certain periods and new ones should be placed in their places.

- The capacities of the classrooms must be increased; they must be made larger and more comfortable.

- Replacement of the tables and chairs in the classrooms.

What I think about making the current studios (workshops) more suitable for teaching practical classes are:

- The workshops must be specialized.
- Machintosch computers must be available on a regular basis and the loaded programs must be usable and up to date.

- Computers must be available for usage whenever the students wish.

- Increasing the number of studios.

- Lockers must be placed in the studios.

What I think about the things that need to be done in order to make the existing technological infrastructure and equipment for all of my works that need to be done in desktop publishing and in digital setting are:

- Tailor-made technological tools and equipment must be provided to each student and the number of instructors of practical classes must be increased.

- The informatics equipment must be provided according to the needs of the age.

- Xerox and equipment to receive any type of print must be available.

\section{Section 4: Instructors and Lesson Content}

In this section, the students were asked to evaluate the instructors teaching in the graphic design program in terms of qualification, experience, field command, lecturing skill, attitude in measurement-evaluation, communications skills and competency in student motivation and orienting.

Table-15: "The instructors are competent in teaching theoretical lessons or the parts requiring lesson teaching."

\begin{tabular}{|l|l|}
\hline Yes & $34(85 \%)$ \\
\hline No & $6(15 \%)$ \\
\hline
\end{tabular}

$85 \%$ of the students found the instructors competent in teaching theoretical lessons. $15 \%$ found the instructors incompetent in terms of qualification and field command.

Table-16: “The instructors are qualified in teaching, showing and having made the lessons requiring practice."

\begin{tabular}{|l|l|}
\hline Yes & $31(84 \%)$ \\
\hline No & $9(16 \%)$ \\
\hline
\end{tabular}

$84 \%$ of the students indicated that they found the instructor competent in teaching, showing and having made the lessons that require practice, and $16 \%$ found them incompetent.

Table-17: “The instructors use the existing conditions in the utilization of technology and have it utilized."

\begin{tabular}{|l|l|}
\hline Yes & $33(83 \%)$ \\
\hline No & $7(17 \%)$ \\
\hline $83 \%$
\end{tabular}

$83 \%$ of the students thought that the instructors used the existing conditions in the utilization of technology and have it utilized, $17 \%$ thought the opposite.

Table-18: “Are you planning to have a graduate (master's/proficiency in art/doctorate) study in your department?"

\begin{tabular}{|l|l|}
\hline Yes & $22(83 \%)$ \\
\hline No & $18(17 \%)$ \\
\hline
\end{tabular}


$22 \%$ of the students planned to pursue a graduate education in the department of their graduation following graduation, and $18 \%$ did not plan a graduate education in their department.

Yes;

University Preferences: Hacettepe, Abroad (USA/Poland), Başkent University, Mimar Sinan Fine Arts University, Bilkent University, Anadolu University, Daimstadt University Department Preferences: Mobile application, packaging design, graphic design, animation, cinema-TV

Table-19: "Do you think your theoretical, practical and technology utilization skill you gained in the design field at the Faculty of Fine Arts, Design and Architecture will have sufficient contribution in your professional work life within the country and abroad and in your educational life that you possibly will continue?"

\begin{tabular}{|l|l|}
\hline Yes & $29(73 \%)$ \\
\hline
\end{tabular}

\begin{tabular}{l|l} 
No & $11(27 \%)$
\end{tabular}

$37 \%$ of the students thought that what they learned would contribute to their professional work life and future educational processes, and $11 \%$ refused it.

No:

- The majority of the students learn computer programs in courses out of school. Knowledge and experience opportunity given on computer programs are insufficient.

- Class contents are below world standards.

- Computer equipment is below standards.

- Physical equipment of the studios in the school is insufficient.

\section{Conclusion}

The vision of Başkent University in the art and design education being candidate to share the honor proven in the science was evaluated regarding the current educational environment, instructors, course contents and environmental factor and opportunities with the ideals of the students registered to the Graphic Design Program dependent on the Department of Visual Arts and Design; the results related to the ideals of students and the success of the program and suggestions regarding the solution of the current problems were evaluated.

The sample selected in the present investigation, conducted by reaching 40 students out of 65 registered at Başkent University, Faculty of Fine Arts, Design and Architecture, Department of Visual Arts and Design, Graphic Design Program, represented the universe. The entirety of the students was 18 years of age and older (Table 2). This leads to the conclusion that their decisions and evaluations belong to a sample regarded as "adults".

The majority of the participants were $1^{\text {st }}$ grade students, and when it is considered that the surveys providing data to the research were conducted in the "spring" semester; they were found competent in the evaluation of the school, department and physical equipment, and class contents and the instructors with the fundamental classes that they took. 6 of the remaining students ( 22 students) were repeating the grade and this pointed to an approximately $1 / 3$ quantity (Table 3). It is possible to say that the success levels of the students who participated in the survey are above the average (Table 4).

$1 / 4$ of the students graduated from the colleges and
Fine Arts High School located in Ankara, only 3 of them completed high schools located out of the Capital. Ankara is the capital of Turkey, and is one of the cities where the educational opportunities are at the highest level. We can say that nearly the entirety of the students benefited from educational opportunities of the capital and the quarter of them used these opportunities at the highest level and completed high school.

Regarding the living settings of the students, it was observed that 6 of them lived without their families; alone, in dormitory or with their friends (Table 5). The majority provide their basic needs in their families such as sheltering and safety. When Table 6 is examined, it is possible to say that monthly incomes of the students were in a level to meet their basic needs and to be sufficient for their school expenses in the conditions of Turkey - especially when the minimum wage is considered (Official Newspaper, December 31, 2014, No. 292222).

$1 / 4$ of the students considered enrolment in graphic design department or program among their ideals (Table 7); approximately half of these expressed that they did not see Başkent University among their ideals (Table 8). Bilkent University and Hacettepe University were determined as the two universities outstanding among the student ideals. Moreover, nearly the entirety of the students expressed that they selected these departments with the support of their families (Table 9). Nevertheless, it was determined that the ratio of those who say that they enrolled in this department as a result of their university settlement scores was $35 \%$, which was substantial (Table 10). 
$72,5 \%$ of the students expressed negative opinion as their graphic design education did not meet their expectations (Table 11). $1 / 4$ of the students evaluated the conditions of the existing classrooms as unsuitable (Table 12). Nearly the same number of students expressed unfavorable opinion about the practice workshops (Table 13). Half of the students found the technological substructure sufficient, and the other half found it insufficient (Table 14).

In the evaluation of the instructors by the students, $85 \%$ of them found the instructors competent in lecturing and practice stages (Table 15). Nevertheless, according to the majority of the students, the instructors used the existing substructure effectively (Table 17). However, approximately half of the students thought to continue graduate studies in their department following undergraduate education (Table 18). In addition, those who thought that graduate education in their department was qualified to support their opportunities within the country and abroad and their professional work life, was approximately $3 / 4$ rate (Table 19 ).

\section{Suggestions}

The suggestions to be made to the research results have concentrated on the articles, where the students evaluated the existing conditions and focused on their ideals. In this regard, it wouldn't be wrong to state that the samples that are taken to the theoretical framework of the study have a characteristic to illuminate the interpretation of the results and solution of the problems. In this framework, the suggestions are listed below:

- The students of Başkent University, Faculty of Fine Arts, Design and Architecture, Department of Visual Arts and Design found the existing physical and technological equipment insufficient substantially. In this case, it is necessary for the existing conditions to reach today's design opportunities, technological substructure such as computers and out of class study settings of the students are prepared.

- When it is considered that the success level of the majority of the students is above the average, it is possible to see that their expectation to receive graduate studies in their own university and department is a natural result of this. Absence of a graduate program in Graphic Design field at Başkent University within the existing conditions cause the students to orient their potential to different universities and make them obligated to build their future in different educational settings. Preventing this is for certain in the responsibility of Başkent University and the concerned units.
When the broad vision of the University about the future and its competency is considered, programming of the future setup that is desired turns out to be the job of the instructors. Therefore, department administrators and instructors should undertake the required responsibility and must act immediately to open up undergraduate and graduate departments and programs such as graphic design and animation under the design, industrial product design.

- It was seen in the data clearly that the students wish to express themselves abroad as much as within the country. Therefore, in order for the students to benefit overseas opportunities the best way, Erasmus modification programs must be operated well and in its aftermath, they should receive education abroad sufficiently in terms of both language and design.

- On-the-job training must be completed by the instructors who have weak communication with the students and cannot keep up with the technological developments or they must be drawn away from the educational setting. The instructors who are not competent in their field must be dismissed from job.

- In order to support meeting of the deficiency in animation area in Turkey, the qualified approach of Başkent University in science and art fields must be supported by considering the demand in this field and development of the animation field must be assisted not only as a student demand, but in order to support country progress.

- Animation field consists of many sub branches within itself. In addition to be informed about each sub branch, expertise within a single field is necessary for success. Therefore, expertise in both work and educational field should be cared in Turkey, and especially the instructors should teach their own expertise areas.

\section{References}

1) Official Newspaper, 31 December, 2014 Wednesday, Number: 292222

2) N, Karasar. Scientific Research Method. Ankara: Nobel Publishing, Distribution, 2002.

3) 3.http://www.animationcareerreview.com/articles/top-100schools-animation-gaming-and-design?page $=0,8$

4) http://pro.boxoffice.com/statistics/alltime_numbers/domestic/ data

5) http://www.trt.net.tr/45yil/Default.html

6) http://www.bilisimdergisi.org/s147

7) http://www.notablebiographies.com/newsmakers2/2004-QZ/Tartakovsky-Genndy.html

8) http://www.notablebiographies.com/newsmakers2/2005-AFi/Bird-Brad.html

9) http://www.imdb.com/name/nm0005124/ 
10) http://www.imdb.com/name/nm0083348/

11) http://www.imdb.com/name/nm0004056/

12) http://www.imdb.com/name/nm0230032/?ref_=fn_al_nm_1

13) http://www.pixartalk.com/pixarians/pete-docter/

14) https://calarts.edu

15) http://www.imdb.com/name/nm0850733/?ref_=fn_al_nm_1

16) http://git.ibu.edu.tr/index.php/tr/

17) http://www.akademik.adu.edu.tr/fakulte/iletisim/default.asp?i $\mathrm{dx}=313930$

18) http://www.aku.edu.tr/anasayfa/Default.aspx

19) http://gsf.akdeniz.edu.tr/tr

20) 20.https://www.anadolu.edu.tr/akademik/fakulteler/192/guzel -sanatlar-fakultesi/genel-bilgi

21) 21.https://www.atauni.edu.tr/kutuphane/galeri/?content $\% 2 \mathrm{Ffa}$ kulteler\%2Fguzel_sanatlar\%2F

22) 24.https://www.atauni.edu.tr/kutuphane/galeri/?content $\% 2 \mathrm{Ffa}$ kulteler\%2Fguzel_sanatlar\%2F

23) 22. http://gsf.atilim.edu.tr

24) 23.

http://www.bitliseren.edu.tr/AkademikBirim.aspx?Program= $37 \& z \mathrm{cms}=429$

25) 24 . http://www.beykent.edu.tr/akademik/lisans/guzelsanatlar-fakultesi

26) 25. http://guzelsanatlar.batman.edu.tr

27) 26. http://gsf.cbu.edu.tr

28) 27. http://gsf.beun.edu.tr

29) 8.http://www.cumhuriyet.edu.tr/fakulte.php?cubid=z8Tg4tTp 19Toyemyj6Gcx9v10uHZ3Nlnpoc $=\&$ Dil $=$ TR

30) 9. http://gsf.comu.edu.tr/index

31) 30. http://gsf.karatekin.edu.tr

32) 31. http://gsf.cu.edu.tr

33) 32 .

http://www.dogus.edu.tr/tr/akademik/sanat/sanat_dekan.asp

34) 33. http://www.deugsf.com

35) 34. http://gsf.dpu.edu.tr

36) 35. http://iletisim.ege.edu.tr

37) 36. http://guzelsanat.erciyes.edu.tr

38) 37. https://www.ogu.edu.tr/Akademik/Detay/FakultelerSanat_ve_Tasarim_Fakultesi/2/51

39) 38. http://gsf.fatihsultan.edu.tr

40) 39. http://web.firat.edu.tr/resimisogrt/

41) 40. http://gsf.gazi.edu.tr/

42) 41. http://stf.gazi.edu.tr/

43) 42.

http://www.gantep.edu.tr/ab/index.php?bolum_id=20255815

44) 43. http://www gedik.edu.tr/akademikbirimler/fakulteler/guzel-sanatlar-ve-mimarlik-fakultesi

45) 44. http://ggsf.giresun.edu.tr/

46) 45. http://www.gsf.hacettepe.edu.tr/?lang=tr

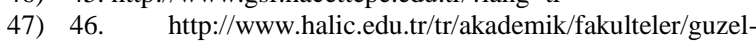
sanatlar-fakultesi

48) 47. http://web.harran.edu.tr/gsf/tr/

49) 48. http://www.hku.edu.tr/AkadamikKadro/Guzel-Sanatlarve-Mimarlik-Fakultesi/58

50) 49. http://www.gstmf.hitit.edu.tr/

51) $50 . \quad$ http://www.igdir.edu.tr/g\%C3\%BCzel-sanatlarfak\%C3\%BCltesi\#

52) 51 http://www.isikun.edu.tr/akademik/fakulteler/guzelsanatlar-fakultes

53) 52. http://www.art.bilkent.edu.tr/

54) 53. https://www.inonu.edu.tr/tr/cms/gsf

55) 54. http://art.ipek.edu.tr/
56) 55. http://www.arel.edu.tr/guzel-sanatlar-fakultesi

57) 56 .

http://www.ebs.aydin.edu.tr/index.iau?Page=FakulteGenelBil giler\&FK=4

58) 57 http://www.bilgi.edu.tr/tr/programlar-veokullar/lisans/iletisim-fakultesi/

59) $58 . \quad$ http://www.esenyurt.edu.tr/kategori/sanat-ve-sosyalbilimler-fakultesi/38

60) 59. http://gsf.gelisim.edu.tr/

61) 60 .

http://www.medeniyet.edu.tr/sanat ve tasarim fakultesi.htm

62) 61 http://www.kemerburgaz.edu.tr/akademikbirimler/guzelsanatlar.aspx?SectionID $=\mathrm{cOz} 8 \mathrm{Qugez} \% 2 \mathrm{fPR} 2 \mathrm{z}$ NcCX\%2f7PA\%3d\%3d

63) 62. http://iletisim.istanbul.edu.tr/

64) 63. http://fadf.ieu.edu.tr/tr

65) 64. http://www.izmir.edu.tr/gsf/

66) 65. http://www.khas.edu.tr/571/fakulte-hakkinda

67) 66. http://www.kafkas.edu.tr/gusf

68) 67. http://gsf.kku.edu.tr/

69) 68. http://guzelsanatlar.ksu.edu.tr/

70) 69. http://gsf.kocaeli.edu.tr/

71) 70.

http://www.karatay.edu.tr/?sayfa=9050ffa91fea5b6e57ebb39f 85548183

72) 71. http://gsf.maltepe.edu.tr/

73) 72. http://gsf.marmara.edu.tr/

74) $73 . \mathrm{http}: / / \mathrm{www} . \mathrm{mersin} . e d u . t r / a k a d e m i k f / g u z e l-s a n a t l a r-$ fakultesi

75) 74. http://www.msgsu.edu.tr/faculties/guzel-sanatlar-fakultesi

76) 75. http://www.gsf.mu.edu.tr/

77) 76. http://www.mku.edu.tr/main.php?location=gsf

78) 77. http://gsf.nevsehir.edu.tr/

79) 78. http://www.konya.edu.tr/guzelsanatlar

80) 79. http://www.nisantasi.edu.tr/fakulteler-ve-departmanlar2/fakulteler-/-bolumler/sanat-ve-tasarim-fakultesi/dekaninmesaji

81) 80. http://guzelsanatlar.omu.edu.tr/

82) 81. http://mtgsf.osmaniye.edu.tr/

83) 82. http://gsf.odu.edu.tr/

84) $83 . \quad$ http://www.sabanciuniv.edu/tr/fakultelerprogramlar/sanat-ve-sosyal-bilimler-fakultesi

85) 84. http://www.gsf.sakarya.edu.tr/tr

86) 85. http://gsf.sdu.edu.tr/

87) 86. https://www.selcuk.edu.tr/guzel_sanatlar/tr

88) 87. http://guzelsanatlar.trakya.edu.tr/

89) 88. http://www.etu.edu.tr/c/index6e71.html?q=tr/gsf-dekanlik

90) 89. http://erdogan.edu.tr/fakulte/gsf/

91) 90.

http://www.tunceli.edu.tr/akademik/fakulteler/guzelsanatlar/i ndex.asp

92) 91. http://gsf.uludag.edu.tr/

93) 92. http://gsf.usak.edu.tr/

94) 93. http://stf.yasar.edu.tr/

95) 94.

http://www.yyu.edu.tr/abis/fakulte personel.php?bolumid=7

96) 95 .

http://www.yeniyuzyil.edu.tr/GuzelSanatlarFakultesi/GuzelS anatlar.aspx

97) 96. http://www.yeditepe.edu.tr/fakulteler/guzel-sanatlarfakultesi 